\title{
Effectiveness and Efficiency of Administrative Appeal Procedures: a Case Study on Tax Disputes in Romania ${ }^{1}$
}

\author{
Octavian Moldovan \\ Babeş-Bolyai University, Faculty of Political, Administrative and Communication \\ Sciences, Romania \\ octavian.moldovan@fspac.ro \\ https://orcid.org/0000-0002-8083-8107
}

\author{
Gabriela Bucătariu \\ Lăpușan \& Partners Law Firm, Romania \\ gabriela.bucatariu@lapusan.law \\ https://orcid.org/0000-0002-5491-4188
}

Received: 6. 8. 2019

Accepted: 14. 10. 2019

\section{ABSTRACT}

The aim of this article is to evaluate the effectiveness and efficiency of (internal) administrative appeal in tax or fiscal matters in Romania, in comparison to the more time and resource consuming court action against an administrative decision imposing fiscal obligations. In order to evaluate the effectiveness and efficiency of administrative appeals, we analysed data from the reports and documents issued by the Romanian National Agency for Fiscal Administration (NAFA) regarding efficiency related indicators, as well as dispute settlements and the amount of collected tax as effectiveness criteria. Furthermore, data regarding the results of the administrative procedure is compared to the results of the judicial procedure in terms of the number of admitted legal actions that annulled fiscal obligations. The results show that at least in the 2013-2017 period, the administrative procedure was both inefficient and ineffective since, on average, less than $7 \%$ of fiscal disputes were solved/settled in favour of the appellant. Moreover, the procedure was rather time consuming although the disputes should have been settled in 45 days, the answer was provided after 70 days. Hence, the administrative procedure is often seen as a mere stepping stone toward subsequent legal/court actions, with no possibility to provide a satisfactory solution and thus lessen the workload of the court. Surprisingly, the taxpayers seem to consider the

1 A previous version of this research was presented at the $27^{\text {th }}$ NISPAcee Annual Conference held in Prague (May 24-26, 2019) in the Rule of Law \& Public Administration panel; only the abstract was published in the conference proceedings. We are grateful to all panel participants and the two coordinators (Polonca Kovač and Anamarija Musa) for their valuable inputs which allowed us to considerably improve our research. 
courts as a more favourable/efficient means as more than half of legal actions brought against fiscal administrative acts were settled in favour of the taxpayer, i.e. the fiscal obligations were annulled. The effectiveness of the preliminary administrative procedure was further analysed from multiple perspectives pertaining to the players that have a direct or indirect legitimate interest in this procedure. These are (i) the courts, which should/could benefit from a reduced workload if the procedure was effective, (ii) the taxpayers filing administrative appeals, which could have a feasible alternative to the time and resource consuming judicial means, and (iii) the fiscal bodies that issued fiscal administrative acts or that must respond to the appeals. The fact that this procedure is a mandatory predecessor of the judicial one and not an alternative means of dispute resolution seems to significantly impede its efficiency and effectiveness. The results can serve as a basis to analyse and compare the respective data in other countries with similar legal and tax systems.

Keywords: administrative appeal procedure, judicial procedure, tax disputes, effectiveness, efficiency, tax/fiscal administration, Romania

JEL: D73, J52, K34

\section{Introduction}

The internal administrative appeal can be seen as one of the two means by which an interested party can appeal against a decision considered unlawful, alongside the judicial review - or court action (Dragoș and Neamțu, 2013, p. 72). More specifically, the administrative appeal is 'a request addressed to a public authority by which the aggrieved person asks for an administrative measures to be taken regarding the administrative decision: annulment, modification or even issuance of a decision - when this has been refused by the administration' (Dragoș and Neamțu, 2013, p. 72), while judicial review can be defined as 'a contested (adversary) proceeding by which an individual brings a conflict with a public authority to the (administrative) courts' (Dragoș and Neamțu, 2013, p. 72; also see Dragoș, Swora and Skoczylas, 2012, pp. 3940; Dragoș, 2011, pp. 100-107).

In this respect, it is important to observe the difference between the common procedure of the administrative appeal applicable for administrative decisions/ acts (except the cases where there is a special regulation) and the specific rules applicable for tax decisions and other measures of the fiscal authorities. Thus, in general (i.e. according to Law no. 554/2004, the general regulation concerning the decisions and measures of public authorities), an administrative decision is not annulled, but revoked by the issuing authority. That means that an administrative appeal, according to the general rules, is in fact always settled by the issuing authority, but only if the contested decision has not been executed yet. If the contested administrative decision is effective by the time the administrative appeal has to be settled, the issuing authority is not allowed to revoke it even if the administrative appeal is considered valid, and 
the only remedy available is the judicial review. Therefore, if the administrative decision is executed, the administrative appeal becomes a useless procedure. The ineffectiveness of the administrative appeal in this cases was recently (or finally) recognized in the Romanian legislation, considering that according to Law no. 212 from August 2nd, 2018, the administrative appeal is no longer a mandatory preliminary procedure, before the judicial review, for the decision of the public authorities that already produced legal effects.

By exception, Romania has specific rules for tax decisions and other decisions of the fiscal authorities, therefore the usual administrative appeal governed by Law no. 554/2004 is inapplicable. The main differences, according to the Romanian Fiscal Procedure Code (Law no. 207/2015) are in fact essential: (i) the fiscal administrative appeal is always mandatory, regardless of the moment the tax decision produces its legal effects; (ii) the terminology regarding a favorable solution to the administrative appeal is not only a formal one - the decisions of the fiscal authorities are annulled, not revoked, if the arguments sustained in the administrative appeal are validated; (iii) the administrative appeal formulated against a decision that implies establishing fiscal obligations or with similar effects is not settled by the issuing fiscal body, but by a special structure for administrative appeal, established at a regional or national level within the Romanian National Agency for Fiscal Administration (NAFA from here on), depending on the amount of the fiscal obligations that are contested).

Although the administrative appeal is often presented as an alternative to the judicial review/court action in comparative public law (see Evans, 1993; Darcy and Paillet, 2000; Miranda, 2006), according to Romanian legislation (art. 7 of the Law no. 554/2004) the internal administrative appeal (or the preliminary administrative procedure) is, in general, mandatory in order to pursue future court actions. As such, the issues of efficiency ${ }^{2}$ and effectiveness must be further scrutinized in regard to the internal administrative appeal, which seems to be transformed from a mean of alternative dispute resolution into a simple preliminary procedure for the judicial phase.

The aim of this paper is to evaluate the effectiveness and efficiency of the internal administrative appeal in fiscal matters in Romania, in comparison to the more time and resource consuming court actions against an administrative decision which imposes fiscal obligations. As such, in order to observe if the internal administrative procedure can be effective and efficient in fiscal matters, or if it is just a hollowed out concept which seems good in theory but is fruitless in practice, similar to public private partnerships in Romania (see Moldovan, 2017), the paper will continue with a brief literature review in Section 2 (discussing taxpayers rights and alternative means of dispute resolution, as well as the internal administrative appeal both the European

2 According to Milovanović, Davinić and Cucić (2012, p. 95), 'efficiency is understood as a precondition for preventing appellants from seeking judicial protection and thus reducing the workload of the court'. 
level and at the national one) and a methodological section (presenting the main data sources and the data collection and analysis procedure). The main results will be discussed in Section 4, under a double sub-heading dealing with both (i) a comparative analysis of the internal administrative and legal/court actions in fiscal matters and (ii) an actor centered game theory analysis regarding the effectiveness of the internal administrative appeal in fiscal matters; the last section (5) concludes and discusses potential further research avenues.

\section{Theoretical background}

\subsection{Taxpayer rights and alternative means of dispute resolution}

Even if the primary role of taxation is to ensure sufficient funding for the state to provide and redistribute social goods, taxpayer rights are nonetheless necessary to protect citizens and to limit how far the state can reach in its grasp for resources, especially in the context of globalization (Bentley, 2015). According to the Internal Revenue Service (2014), taxpayers have the following rights: to be informed, to quality service, to pay no more than the correct amount of tax, to challenge the RS's position and be heard, to appeal an IRS decision in an independent forum, to finality, to privacy and confidentiality, to retain representation and to a fair and just tax system. OECD (1990) noted that the basic rights of taxpayers identified in its member states (to be informed, assisted and heard, to appeal, to pay no more than the correct amount of tax, to certainty, to privacy and to confidentiality and secrecy) also imply basic obligations on taxpayers behalf (to be honest, to be co-operative, to provide accurate information and documents, to keep records and to pay taxes in time). Bentley (2015, pp. 8-9) argues that a legitimate and effective tax framework cannot be built in void and must be based on a set of taxation principles, such as: equity and fairness, certainty and simplicity, efficiency, neutrality and effectiveness.

Bentley (2015, pp. 10-11), based on an extensive review of documents (ranging from constitutions to treaties, legislation, administrative charters and service standards) provides a list of 16 basic taxation rights which are assume to protect taxpayers and the basic taxation principles from which they are derived, as shown in Table 1. 
Table 1: Primary Legal Rules to protect taxpayers' rights

\section{Taxation rights}

1. Tax must be imposed by law

2. Tax law must be published

3. Tax law must not be imposed retroactively

4. Tax law must be understandable

5. Tax law must not be contradictory

6. Taxpayers must be able to obey the law

7. Frequent change must not undermine the tax law

8. Tax law must be applied

9. Taxpayers need to pay no more than the correct amount of tax

10. Tax law should not impose double taxation

11. Tax rules should not discriminate and there should be equality before the law

12. Tax rules should satisfy the principle of proportionality

13. Taxpayers should have the right to privacy

14. Taxpayers should have the right to confidentiality and secrecy

15. Taxpayers should have the right of access to information

16. Taxpayers should have the right of access to the courts, which should demonstrate the following characteristics:

- an independent and impartial tribunal;

- a fair and public hearing;

- a fair trial;

- the right to remain silent;

- the right to representation; and

- public judgment within a reasonable time.

\section{Reference to the basic principles}

Tax rules should not be arbitrary

Tax rules should be transparent

Taxpayers should be able to anticipate in advance the consequences of a transaction

Tax rules should be certain, clear and simple to understand

Tax rules should be certain

Tax rules should be effective and certain

Tax rules should be certain

Tax rules should be certain, fair, transparent and effective

Tax rules should be effective and certain

Tax rules should be fair and effective

Tax rules should be fair and equitable

Tax rules should be effective, fair and equitable

Source: Adapted after Bentley, 2015, pp. 10-11 
Besides the previously discussed basic rights and legal principles, taxpayers can often also use alternative means of disputed resolution (ADR from here on) to settle their divergences with tax administration bodies. ADR differs from both the internal administrative appeal and from the court/judicial review as usually a third party (not the court) is brought in with the agreement of both parties to offer a mutually satisfactory solution. According to the International Monetary Fund $(2013$, p. 31) ADR 'can involve procedures that are more flexible and less burdensome for the taxpayer as well as being more cost effective for the tax administration', without undermining the rule of law; furthermore, ADR mechanism are often appropriate in cases where the law is open to interpretation and fiscal/taxation decisions were made with the use of administrative discretion. Depending on the situation, the type of the taxpayer and its relationship with the tax administration body, we can distinguish between multiple ADR mechanisms (International Monetary Fund, 2013, pp. 32-40; Parsly, 2007, pp. 677-715; Tran-Nam and Walpole, 2012, p. 479):

- A cooperative approach to large taxpayers, which are often in a more reduced number, have greater capacity to challenge the decision made by tax administration and generally contest or dispute significant amounts. Tax administration bodies often build and maintain a special relationship with large taxpayers.

- Mediation / conciliation by an independent third party as 'both parties accept a third party intervention in the procedure to get them together in cases where it is no longer possible for them to reach an agreement on their own' (International Monetary Fund, 2013, p. 33). The conciliator/mediators helps the parties identify disputed issues, consider multiple alternative solutions and reach a mutually satisfactory solution; the mediator often assumes a lighter role as it does not 'give advice on the content', but the difference between the two is often blurred in practice.

- Settlements or agreements between the two parties which can often occur in the pre-trial period or even during litigations; fast track settlement programs can be designed for large, mid-size or small businesses and even for self employed (Parsly, 2007, pp. 691-697).

- Arbitration, in which both taxpayers and tax administration agree to bring in an independent third party and accept its decision.

- A tax ombudsman institution can also help settle disputes or prevent them from arising by ensuring a better interaction between tax officials/bodies and taxpayers.

Based on an empirical research conducted on 340 Australian taxpayers (ranging from individuals to micro/small and even large businesses) involved in different ADR mechanisms (conciliation, mediation and evaluation) between 2013 and 2014, Sourdin (2015, p. 13) concluded that 'the perceptions of those involved in the ADR processes were generally very positive', 'the processes were fair and if a settlement did not occur at the intensive ADR session, that the ADR event had an impact on finalization of the dispute within a short time 
frame'; furthermore, ADR was seen as being both cost and time effective. According to Tran-Nam and Walpole (2012) classical forms of tax dispute resolution (such as the internal administrative appeal or judicial review) entail multiple cost for taxpayers, ranging from explicit ones (monetary expenses) to implicit ones (opportunity cost of lost time or psychological cost) which make them ineffective; as such, we could posit that alternative dispute resolution procedures (such as the ones presented above) could alleviate these costs and represent more socially just means to settle tax disputed.

\subsection{Internal administrative appeal in the EU}

Although from a chronological perspective administrative legal remedies (such as the internal administrative procedure) were the first forms of controlling the activity of the administration (preceding alternative means of dispute resolution), they 'did not lose their position and significance in the process of protection of rights and legal interests of private parties (natural persons and organizations) vis-à-vis administration', are 'equally important means for the protection of legality and public interest' and 'remained a vital ingredient in the proceeding for review of administrative acts' (Cucić, 2011a, p. 51).

Administrative legal remedies are often assumed to 'help developing greater respect for individuals' rights and freedoms and building a climate of confidence between administration and citizens' (Cucić, 2011a, p. 51) and to 'keep judicial disputes to a minimum and relieve the workload on the courts' (Themis Project, 1997, p. 149), thus such mechanisms are also being consistently encouraged and promoted by the Council of Europe (1980; 2001; 2007). Furthermore, according to the World Bank (2019, p. 3) a 'well-designed internal administrative process for reviewing tax decisions can contribute to economic efficiency, competitiveness, and growth by accurately identifying errors in tax administration, lowering compliance costs for taxpayers, and enhancing the credibility and popular legitimacy of the tax regime'.

As Kovač (2013, p. 40) mentions, the administrative appeal, as any other legal remedy, 'must be (1) easily accessible and well publicised, (2) simple to understand and use, (3) speedy, with established time limits for action, and the parties kept informed of progress, (4) fair with a full and impartial investigation, (5) effective, namely addressing all the points at issue, and providing appropriate redress, and (6) informative, i.e. providing information to management so that service can be improved'. The World Bank (2019, pp. 28-44) also offers a list of international good-practice principles in the case of administrative tax review, as follows: (1) to legally define the rules of the process; (2) to harmonize internal review procedures; (3) to ensure the independence of the review institution; (4) to communicate effectively with the public and with taxpayers involved in the review process; (5) to resolve disputes as early in the process as possible; (6) to collect, publish, and report performance data; (7) to embrace ICT solutions; (8) to train officials 
continuously; (9) to improve the quality of tax documents, and (10) to establish and use performance indicators.

Albeit empirical literature on internal administrative appeal in the EU is rather scarce as the lion's share of work in the field is either theoretical, legally focused or based on single case (country) studies, there are a few sources which have to be carefully reviewed in order to provide a better understanding of the phenomena. For example, Kovač (2013) compared administrative appeals and court actions in Slovenia between 2007 and 2011 and found that although the number of acts issued by Administrative units has increased, the number of appeals has decreased; furthermore, 'approximately $20 \%$ of the denied appeals parties decide to pursue further court action' and that 'the number of appeals and court actions seems to depend more on the awareness of the right to legal remedies than on mistrust in the administration' (Kovač, 2013, p. 46). Veny and De Munck (2011, pp. 278-279) distinguish in the case of Belgium between three types of appeal, namely: 'appeal in reconsideration with the organ that made the decision', 'hierarchic appeal with the hierarchic superior of the authority concerned' and 'an appeal can be lodged with the authority exercising administrative supervision'. Dragoș, Swora and Skoczylas (2012, p. 38) conducted a comparative analysis of administrative appeals in Romania and Poland in order to 'highlight that currently the European national systems are fluid and continuously changing' and to 'identify best practices that could be transferred from one system to the other'. Based on the analysis of the legal frameworks of the two procedures, the authors concluded that the 'administrative appeal seems to be regulated in a similar manner in the two jurisdictions assessed, but differences still exist on the degree of formalization of the procedure' (Dragoș, Swora and Skoczylas, 2012, p. 51). Klonowska (2017, pp. 98-99) analyzed the 2016 decisions of the Polish Voivodship Administrative Court and noticed that decisions regarding tax matters represent one third of all matters settled and the courts granted $21 \%$ of them, while 'in 2013 voivodship administrative courts granted over $30 \%$ of complaints about acts and activities of tax chambers and inspectors of fiscal control offices, while in 2012 only 26\%'.

According to Milovanović, Davinić and Cucić (2012, p. 96), in the case of Serbia, the administrative appeal can be described as having the following characteristics 'its use is mandatory prior to access to judicial review; it is, as a rule, allowed against all first instance administrative acts, it has a devolutionary effect; it has, as a rule, suspensory effect; it can be used to challenge all forms of illegality, as well as inopportunity (misuse of discretionary powers) of an administrative act, when submitted by a private party; it has non reformatio in peius effect; it can be used for challenging both the acts and the 'silence' of the administration, if it finds the appeal to be founded, appellate authority can annul or alter the challenged administrative act' (also see Cucić, 2011b, p. 65). 


\subsection{Internal administrative appeal in Romania}

According to Dragoș and Neamțu (2013, pp. 73-74) and Dragoș, Swora and Skoczylas (2012, p. 40) the Romanian law includes all the possible forms of the administrative appeal, referring to:

- objection and hierarchical appeal, as regulated by Law no. 554/2004; and

- quasi or improper hierarchical appeals, as the appeal of the prefect against decisions issued by local governments, the appeal of the Romanian National Agency for Civil Servants against 'public bodies that infringe the legal provisions regarding civil service' (Dragoș and Neamțu, 2013, p. 73), the control of the Romanian Court of Auditors or even actions of the Romanian Ombudsman.

Previous analyses of the Romanian administrative appeal were often limited to theoretical approaches regarding this procedure such as explaining the steps, timeframe, penalties for not respecting deadlines (Tăbârcă, 2009) or the influence/impact of other laws (such as New Civil Procedure Code) on the preliminary procedure (Ursuţa, 2012). Ursuţa (2012, p. 152) noticed that the internal administrative appeal was partially changed by the New Civil Procedure Code, as 'although the preliminary procedure remains mandatory in the field of the contentious-administrative, the exception of procedure by which this aspect is invoked must be formulated in extremely restrictive conditions'. However, the effectiveness and efficiency of the administrative appeal are often called into question in the case of Romania, as 'The general perception is that administrative appeals are just a nuisance for those who seek access to justice. This opinion is largely endorsed by lawyers, who are not charging for representing parties in administrative procedures, and are eager to get to court as soon as possible. A possible explanation is also the low trust in public administration, lower even than the one in the justice system' (Dragoș and Neamțu, 2013, p. 74-75).

The effectiveness and the efficiency of the internal administrative appeal were seldom researched in Romania; one of the few if not only study on the topic was conducted by Dragoș and Neamțu (2013) and consisted of both a national survey (including all the prefects, municipalities, cities and multiple communes from each of the 41 Romanian counties and the capital city) and a semi-structured interview with representatives of local public authorities. According to their results, in the 2004-2009 period less than 1\% of administrative acts were challenged by legal or natural persons in front of the issuing authority $(0.07 \%$ in the case of urban authorities and $0.04 \%$ in the case of rural ones) while the 'percentage of administrative acts revoked/ modified by the issuing authority is $34.2 \%$ for the urban sub-sample and $48.97 \%$ for the rural one from the total number of acts against which an internal administrative appeal was lodged' (Dragoș and Neamțu, 2013, p. 77). Furthermore, the "success rate' for the internal administrative appeal lodged by legal or natural persons is above $50 \%$ (the efficiency threshold 
as defined by the authors), namely $64 \%$. This means that only in $36 \%$ of the cases a subsequent court action has been filed. No significant difference was discovered between the rural and the urban communities in this respect' (Dragoș and Neamțu, 2013, p. 78).

In the case of the prefect (who has to control for legality all the acts issued by local public authorities), the results showed that, on average, per county per year, 154 acts were requested to be reconsidered by the issuing authorities, while the "success rate" for the internal administrative appeal in the case of the prefect is quite high, namely $87 \%[\ldots]$ since only in $13 \%$ of the cases the local public authorities uphold their initial decision (considered illegal by the prefect) and decide to go to court' (Dragoș and Neamțu, 2013, p. 78).

\section{Methods}

Efficiency, in the context of this work, is understood as the capacity of the internal administrative procedure to generate decisions that are in favor of the appellant and thus reduce the ulterior workload of judicial courts. The aforementioned working definition build on the works of Milovanović, Davinić and Cucić (2012, p. 98) arguing that 'The administrative appeal shall be considered efficient if it diverts at least one half of the appellants from seeking judicial review of the administrative acts, i.e. from submitting suits [tuzba] to the Administrative Court'; the previous definition was based on Willemsen, Gøtze and Dragoş (2010, p. 7). Dragoș and Neamțu (2013, p. 75) consider that internal administrative appeals are efficient if they 'significantly reduce (with over $50 \%$ ) the number of court actions against administrative acts/decisions'. However, we do not fully side with the aforementioned authors and their suggestion to 'mathematically quantify' efficiency by percentages (one half, $50 \%$ and so on) as other factors must be taken into account, such as entry barriers, the length of the procedure, delays or its overall respect for both the letter and the spirit of the law. We believe that a 'comparative benchmark' such as the decision of the court following the judicial review would be more appropriate in this case, as they allow for cross-country and cross-time comparisons which are urgently needed in the research field.

On the other hand, as Kovač (2013, p. 40) mentions, an institution or procedure is effective when 'it meets the objective of its regulation in practice' and that 'effective is that which generally contributes to the main purpose of administrative procedures, i.e. to balance the parties' rights and assert the public interest in accordance with the purpose and content of sector-specific regulations'; thus a more fluid and less constrictive approach to the notion of effectiveness might be needed in order to assess the internal administrative appeal. Effectiveness, in the context of this research, will be defined as the overall capacity of the internal administrative procedure to generate outcomes satisfying the needs of the parties. A differentiation between the two concepts is rather a norm in other fields of research such 
as economics, management, organizational studies, strategic planning, etc. (McCormick, 1981; Bartuševičienè and Šakalytè, 2013; lo Storto and Goncharuk, 2017; Mandl, Dierx and Ilzkovitz, 2008; Codagnone, 2008), but the two concepts are often used inter-changeably in law (at least regarding the present topic, see for example Dragoș and Neamțu, 2013), with few studies addressing the differences between the two (Cornall, 2008; Ransome, 2008; Voermans, ten Napel and Passchier, 2015; European Union, 2015; OECD, 2010; Trinder and Kellett, 2007).

The current research partially follows the model provided by Kovač (2013) of comparing the internal administrative appeal with court actions and some of the indicators used by the aforementioned author, as well as the more narrower focus on specific domains (fiscal in our case) instead of a general approach (as that adopted/utilized by Dragoș and Neamțu, 2013).

The data regarding fiscal administrative appeals and fiscal judicial review (court action) was collected from the reports published by the Romanian National Agency for Fiscal Administration (NAFA) on the official website of the agency) for the 2013-2017 period. The document analysis allowed us to obtain data regarding the following main indicators of interest:

- the number of fiscal administrative appeals registered each year by NAFA;

- the number of appeals for which a decision was taken, the average time in which the appeal was resolved and the decision was made (i.e. if the fiscal obligation was annulled, maintained or other decisions);

- the financial amounts (value of the fiscal obligations) of the annulled or maintained disputed fiscal administrative acts; and

- the number of court actions which received a judicial ruling and the nature of that ruling, as well as the value of the fiscal obligations maintained or annulled.

Data for the 2013-2017 period was gathered from two types of documents available on the official NAFA website, namely:

- statistical fiscal bulletins from the fourth trimester (NAFA 2014a; NAFA 2015a; NAFA 2016a; NAFA 2017a and NAFA 2018a) which include information for the entire year, and

- annual performance reports (NAFA 2014b; NAFA 2015b; NAFA 2016b; NAFA 2017b and NAFA 2018b).

Similar 'official document analysis' methodologies were used by Kovač (2013) to compare administrative appeals and court actions in Slovenia and Macarie and Moldovan (2018) to analyze the evolution of internal public auditing in Romania. 


\section{Results and discussion}

\subsection{The efficiency of administrative appeals and judiciary reviews in Romania}

Table 2 includes the main indicators of interest regarding the fiscal administrative appeal procedure obtained from the documents and reports of the National Agency of Fiscal Administration for the 2013-2017 period. The data shows that the number of fiscal administrative appeals registered by NAFA has been rather decreasing steadily (from 11756 in 2013 to 9647 in 2017) similar to the number of settled appeals (from 11489 to 8730), while the number of administrative appeals still pending at the end of the year can be described as having an upward trend (from 2363 files in 2013 to 2998 in 2017). The number of days in which the administrative appeal was settled also increased during the analysed period, from 62 days in 2014 to 97 in 2017 (Table 2). 
Table 2: Overview of fiscal administrative appeals

\begin{tabular}{|c|c|c|c|c|c|}
\hline Indicator of interest / year & 2013 & 2014 & 2015 & 2016 & 2017 \\
\hline Number of fiscal administrative appeals registered & $\begin{array}{l}11756 \\
\text { files }\end{array}$ & $\begin{array}{l}8814 \\
\text { files }\end{array}$ & $\begin{array}{l}9403^{3} \\
\text { files }\end{array}$ & $\begin{array}{l}7793 \\
\text { files }\end{array}$ & $\begin{array}{c}9647^{4} \\
\text { files }\end{array}$ \\
\hline $\begin{array}{l}\text { Number of fiscal administrative appeals still pending } \\
\text { at the end of the year (no of files) }\end{array}$ & $\begin{array}{l}2363 \\
\text { files }\end{array}$ & $\begin{array}{l}2868 \\
\text { files }\end{array}$ & $\begin{array}{l}3367 \\
\text { files }\end{array}$ & $\begin{array}{l}2081 \\
\text { files }\end{array}$ & $\begin{array}{l}2998 \\
\text { files }\end{array}$ \\
\hline Number of fiscal administrative appeals settled & $\begin{array}{l}11489 \\
\text { files }\end{array}$ & $\begin{array}{l}8309 \\
\text { files }\end{array}$ & $\begin{array}{l}8.909 \\
\text { files }\end{array}$ & $\begin{array}{l}9.083 \\
\text { files }\end{array}$ & $\begin{array}{l}8730 \\
\text { files }\end{array}$ \\
\hline Medium duration of the procedure & $\mathrm{N} / \mathrm{A}$ & $\begin{array}{l}62 \\
\text { days }\end{array}$ & $\begin{array}{c}56 \\
\text { days }\end{array}$ & $\begin{array}{c}60 \\
\text { days }\end{array}$ & $\begin{array}{l}97 \\
\text { days }\end{array}$ \\
\hline $\begin{array}{l}\text { Value of the fiscal obligations that were contested } \\
\text { and settled by the end of the year (million RON) }\end{array}$ & 5705.5 & 8086.4 & 11166.7 & 8820.6 & 5468.0 \\
\hline $\begin{array}{l}\text { Value of the fiscal obligations that were maintained } \\
\text { after the administrative appeals were settled (the } \\
\text { value of the obligations in million RON and the } \\
\text { percentage of the amounts, from the total value of } \\
\text { the fiscal obligations that were contested and settled } \\
\text { by the end of the year) }\end{array}$ & $\begin{array}{l}2608.9 \\
45.7 \%\end{array}$ & $\begin{array}{c}4271.6 \\
52.8 \%\end{array}$ & $\begin{array}{c}4431.7 \\
39.7 \%\end{array}$ & $\begin{array}{l}4058.8 \\
46.0 \%\end{array}$ & $\begin{array}{l}2310.8 \\
42.3 \%\end{array}$ \\
\hline $\begin{array}{l}\text { Value of the fiscal obligations that were annulled } \\
\text { after the administrative appeals were settled (the } \\
\text { value of the obligations in million RON and the } \\
\text { percentage of the annulled amounts, from the total } \\
\text { value of the fiscal obligations that were contested } \\
\text { and settled by the end of the year) }\end{array}$ & $\begin{array}{l}238.8 \\
4.2 \%\end{array}$ & $\begin{array}{l}552 \\
6.8 \%\end{array}$ & $\begin{array}{l}323.9 \\
2.9 \%\end{array}$ & $\begin{array}{l}49.1 \\
0.6 \%\end{array}$ & $\begin{array}{l}57.3 \\
1.0 \%\end{array}$ \\
\hline $\begin{array}{l}\text { Value of the fiscal obligations that were cancelled for } \\
\text { procedural reasons after the administrative appeals } \\
\text { were settled (the value of the obligations in million } \\
\text { RON and the percentage of the annulled amounts, } \\
\text { from the total value of the fiscal obligations that } \\
\text { were contested and settled by the end of the year) }\end{array}$ & $\begin{array}{l}843.9 \\
14.8 \%\end{array}$ & $\begin{array}{l}364.7 \\
4.5 \%\end{array}$ & $\begin{array}{l}389.5 \\
3.5 \%\end{array}$ & $\begin{array}{l}760.2 \\
8.6 \%\end{array}$ & $\begin{array}{l}395.4 \\
7.2 \%\end{array}$ \\
\hline $\begin{array}{l}\text { Value of the contested fiscal obligations from } \\
\text { the files that were settled with other solutions } \\
\text { besides rejection or admitted (the value of the } \\
\text { obligations in million RON and the percentage of the } \\
\text { annulled amounts, from the total value of the fiscal } \\
\text { obligations that were contested and settled by the } \\
\text { end of the year) } \\
\text { "In this cases the administrative appeals was rejected for procedural } \\
\text { reasons as: dismissed as late; was formulated by a person who } \\
\text { did not justify his quality, failure to provide specific reasons, res } \\
\text { judicata, lack of jurisdiction of the fiscal authorities, renunciation, } \\
\text { lack of object, suspension of the administrative appeal). }\end{array}$ & $\begin{array}{l}2013.9 \\
35.3 \%\end{array}$ & $\begin{array}{l}2898.1 \\
35.9 \%\end{array}$ & $\begin{array}{c}6021.6 \\
53.9 \%\end{array}$ & $\begin{array}{l}3952.5 \\
44.8 \%\end{array}$ & $\begin{array}{l}2704.5 \\
49.5 \%\end{array}$ \\
\hline
\end{tabular}

Source: NAFA statistical fiscal bulletins and annual performance reports

3 The actual number of registered files in 2015 was of 21168, but 11765 of them were directed to the competent authorities, therefore only 9403 files represented administrative appeals that should be settled by the fiscal authorities of NAFA.

4 The actual number of registered files in 2017 was of 10076, but 429 of them were directed to the competent authorities, therefore only 9647 files represented administrative appeals that should be settled by the fiscal authorities of NAFA. 
The values of the disputed fiscal obligations which were settled by the end of the year also varied considerably in the analyzed period, from 5705.5 million RON ${ }^{5}$ in 2013 to a peak value of 11166.7 million RON in 2015, only to decrease again in 2017 to 5468.0 million RON (Table 2). Over $40 \%$ of the fiscal administrative appeals settled during the analyzed period maintained the fiscal obligations initially imposed, while these obligations were annulled in significantly lower ratios (between $0.6 \%$ in 2016 and $4.2 \%$ in 2013); a more significant share (between $3.5 \%$ and $14.8 \%$ ) of the contested and settled fiscal obligations were cancelled for procedural reasons. Table 2 also presents a rather intriguing development, as between a third and a half of the values of fiscal obligations which were contested and settled received other solutions besides rejection or being admitted, as the administrative appeals were rejected for procedural reasons as: dismissed as late, was formulated by a person who did not justify his quality, failure to provide specific reasons, res judicata, lack of jurisdiction of the fiscal authorities, renunciation, lack of object, suspension of the administrative appeal.

Table 3 shows that, according to their financial value, only between a half and two thirds of the fiscal obligations that were contested and settled were actually verified on grounds of legality and validity, the ratio decreasing over time from $64.7 \%$ in 2013 to $50.5 \%$ in 2017 . The value of the fiscal obligations which were annulled also decreased over time, from $18.94 \%$ of the value of the fiscal obligations which were contested and settled (in 2013) to 8.18\% in 2017.

Table 3: Contested, verified and annulled fiscal obligations

\begin{tabular}{|c|c|c|c|c|c|}
\hline Indicator of interest / year & 2013 & 2014 & 2015 & 2016 & 2017 \\
\hline $\begin{array}{l}\text { Value of the fiscal obligations that } \\
\text { were contested and settled }\end{array}$ & 5.7 bill. & 8.09 bill. & 11.17 bill. & 8.8 bill. & 5.5 bill. \\
\hline $\begin{array}{l}\text { Value of the fiscal obligations that } \\
\text { were actually verified on grounds of } \\
\text { legality and validity (the value of the } \\
\text { obligations in billion RON and the } \\
\text { percentage of the verified amounts, } \\
\text { from the total value of the fiscal } \\
\text { obligations that were contested and } \\
\text { settled by the end of the year) }\end{array}$ & $\begin{array}{l}3.69 \text { bill. } \\
64.7 \%\end{array}$ & $\begin{array}{l}5.19 \text { bill. } \\
64.2 \%\end{array}$ & $\begin{array}{l}5.14 \text { bill. } \\
46.1 \%\end{array}$ & $\begin{array}{l}4.9 \text { bill. } \\
55.2 \%\end{array}$ & $\begin{array}{l}2.8 \text { bill. } \\
50.5 \%\end{array}$ \\
\hline $\begin{array}{l}\text { Value of the fiscal obligations } \\
\text { that were annulled (the value of } \\
\text { the obligations in billion RON and } \\
\text { the percentage of the annulled } \\
\text { amounts, from the total value of } \\
\text { the fiscal obligations that were } \\
\text { contested and settled) }\end{array}$ & $\begin{array}{l}1.08 \text { bill. } \\
18.94 \%\end{array}$ & $\begin{array}{l}0.92 \text { bill. } \\
11.37 \%\end{array}$ & $\begin{array}{l}0.71 \text { bill. } \\
6.35 \%\end{array}$ & $\begin{array}{l}0.81 \text { bill. } \\
9.20 \%\end{array}$ & $\begin{array}{l}0.45 \text { bill. } \\
8.18 \%\end{array}$ \\
\hline
\end{tabular}

Source: NAFA statistical fiscal bulletins and annual performance reports

5 One Euro had an annual average value of 4.419 Ron in 2013, 4.444 in 2014, 4.445 in 2015, 4.49 in 2016 and 4.468 in 2017. 
Table 4 shows a rather peculiar phenomenon, as although at first sight it would seem that NAFA was rather diligent and resolved (settled) the vast majority of the fiscal administrative appeals registered, the story shifts considerably when we take into consideration the values of the fiscal obligations. As such, the value of the fiscal obligations that were contested and not settled by the end of the year seems to be disproportionately larger when compared to their number.

Based on the data presented in Table 4, we might assume that NAFA is mostly prone to settle a larger number of administrative appeals which refer to smaller financial amounts (and less complex issues) and to delay (intentionally or unintentionally, due to understaffing or other reasons) reaching a settlement in the case of a smaller number of fiscal administrative appeals which refer to more consistent financial amounts. However, we must state that this is just a working hypothesis and that further research is necessary in order to confirm or infirm this observation and to scrutinize the potential reasons behind this phenomena. Unfortunately, if we analyze the performance reports made at a regional level, we will not find an analysis / situation regarding the duration of the administrative appeal. For instance, if we refer to the performance reports of the Regional Directorate of General of Public Finance from Cluj-Napoca ${ }^{6}$, the activity of the specialized structure for administrative appeals is analyzed only briefly, with no reference to the medium duration of the procedure. However, this indicator of interest (the duration of the administrative appeals) is very important in terms of efficiency and effectiveness of the procedure, if we take into account at least two factors: (i) the solution regarding the administrative appeal is a conditionality which delays the judicial review, and (ii) the contested fiscal decisions is enforceable regardless of the duration of the procedure ${ }^{7}$ (thus, the affected individuals or legal persons bare the effects of the administrative decisions, without having the right to challenge it in advance and not even within a reasonable time).

6 A specialized structure for administrative appeals in fiscal matters is established within the Regional Directorate General of Public Finance of Cluj, with competence regarding the tax decisions issued by the fiscal authorities from that region, including 6 counties: Bihor, Bistriţa - Năsăud, Cluj, Maramureş, Satu - Mare and Sălaj.

7 In exceptional and strict conditions and only if a significant bail is deposited, the execution of the tax decision can be granted in a judicial procedure, after the administrative appeal is submitted. 
Table 4: Average duration of the fiscal administrative appeal

\begin{tabular}{|c|c|c|c|c|c|}
\hline Indicator of interest / year & 2013 & 2014 & 2015 & 2016 & 2017 \\
\hline Medium duration of the procedure & N/A & 62 days & 56 days & 60 days & 97 days \\
\hline $\begin{array}{l}\text { Number of fiscal administrative appeals } \\
\text { registered } \\
\text { Value of the fiscal obligations that were } \\
\text { contested }\end{array}$ & $\begin{array}{l}11756 \\
\quad \text { files } \\
7.45 \text { bill. }\end{array}$ & $\begin{array}{l}8814 \\
\text { files } \\
8.99 \text { bill. }\end{array}$ & $\begin{array}{l}940 \\
\text { files }^{8} \\
9.78 \text { bill. }^{2}\end{array}$ & $\begin{array}{l}7793 \\
\text { files } \\
7.1 \text { bill. }\end{array}$ & $\begin{array}{r}9647 \\
\text { files }^{9} \\
8.4 \text { bill. }^{2}\end{array}$ \\
\hline $\begin{array}{l}\text { Number of fiscal administrative appeals } \\
\text { settled by the end of the year }\end{array}$ & $\begin{array}{l}11489 \\
\text { files }\end{array}$ & $\begin{array}{l}8309 \\
\text { files }\end{array}$ & $\begin{array}{l}8909 \\
\text { files }\end{array}$ & $\begin{array}{l}9083 \\
\text { files }\end{array}$ & $\begin{array}{l}8730 \\
\text { files }\end{array}$ \\
\hline $\begin{array}{l}\text { Value of the fiscal obligations that were } \\
\text { contested and settled by the end of the } \\
\text { year (billion RON) }\end{array}$ & 5.7 bill. & 8.09 bill. & 11.17 bill. & 8.8 bill. & 5.5 bill. \\
\hline $\begin{array}{l}\text { Number of fiscal administrative appeals } \\
\text { still pending at the end of the year }\end{array}$ & $\begin{array}{l}2363 \\
\text { files }\end{array}$ & $\begin{array}{l}2873 \\
\text { files }\end{array}$ & $\begin{array}{l}3367 \\
\text { files }\end{array}$ & $\begin{array}{l}2081 \\
\text { files }\end{array}$ & $\begin{array}{l}2998 \\
\text { files }\end{array}$ \\
\hline $\begin{array}{l}\text { Value of the fiscal obligations that were } \\
\text { contested and not settled by the end of } \\
\text { the year (billion RON) }\end{array}$ & 3.3 bill. & 4.21 bill. & 2.82 bill. & 1.1 bill. & 4.0 bill. \\
\hline
\end{tabular}

Source: NAFA statistical fiscal bulletins and annual performance reports

The legal framework regarding the maximum duration of the fiscal administrative appeal, although recently reviewed, is still rather favorable to the fiscal authorities. First of all, the legal term for settling the administrative appeal is 45 days, but this term is not truly mandatory for fiscal authorities, since there is no consequence (penalty or sanction) for exceeding this term. The 'non-mandatory' nature of this term has immediate consequences in the administrative appeal procedures, considering that according to the data from Table 4 the medium duration of the procedure exceeds the period of 45 days.

The legislator's intervention in this respect, while essential in this context, is however not sufficient. According to the Romanian Fiscal Procedure Code applicable until December 31st, 2015 (Government Ordinance no. 92/2003), the decisions of the fiscal authorities had to be appealed in the administrative procedure, while the judicial review could target only the solution given in the administrative appeal. Therefore, in all the cases, irrespective of the duration of the administrative appeal, the individual was forced to wait for a solution to the administrative appeal, in order to ask for the judicial review of the tax decision. According to the new Romanian Fiscal Procedure Code (Law no. 207/2015, applicable starting with January $\left.1^{\text {st }} 2016\right)$, the legal term for settling the administrative appeal is still of 45 day and still there is no sanc-

8 The actual no of registered files in 2015 was of 21168, but 11765 of them were directed to the competent authorities, therefore only 9403 files represented administrative appeals that should be settled by the fiscal authorities of NAFA.

9 The actual no of registered files in 2017 was of 10076, but 429 of them were directed to the competent authorities, therefore only 9647 files represented administrative appeals that should be settled by the fiscal authorities of NAFA. 
tion applied to the fiscal authorities for not settling the administrative appeal within 45 days from the registration date. However, considering the significant delays registered, the legislator has, however, regulated a remedy: if the administrative appeal is not settled in a term of 6 months from the registration date, the applicant is entitled to ask for the judicial review of the contested decision, without waiting (longer) for a solution to his administrative appeal. Even if this legislative change somehow acknowledges the inefficiency of the administrative appeals, at least we have, to some extent, a remedy for the abuse often conducted by fiscal authorities regarding the significant delays which are registered on a usual basis in settling the administrative procedure in fiscal matters. One potential explanation for constantly exceeding the 45 days deadline would be that this a conscious behavior of fiscal administrative institutions which purposefully delay settling contested fiscal obligations in an attempt to 'collect' more financial resources in order to offset other revenue mobilization shortcomings (Moldovan, 2016); even if this solution would be just a short term one, it could still alleviate cash flow problems.

Table 5 presents an overview of the decisions taken by the courts regarding NAFA fiscal administrative decisions that reached the judicial review phase following the internal administrative appeal; in essence, the number of files/ actions in which the judicial courts verified the legality and validity of the fiscal obligations decreased steadily, from 3272 in 2013 to 1182 in 2017.

Table 5: Overview of judicial court's results

\begin{tabular}{|c|c|c|c|c|c|}
\hline Indicator of interest / year & 2013 & 2014 & 2015 & 2016 & 2017 \\
\hline $\begin{array}{l}\text { Number of files in which the judicial } \\
\text { courts verified the legality and validity } \\
\text { of the fiscal obligations }\end{array}$ & 3272 & 1217 & 1322 & $\begin{array}{c}1526 \\
2.6 \text { bill. }\end{array}$ & $\begin{array}{l}1182 \\
525.9 \\
\text { mill. RON }\end{array}$ \\
\hline $\begin{array}{l}\text { Number of files that were rejected and } \\
\text { the total amounts of fiscal obligations } \\
\text { confirmed by the judicial courts (the } \\
\text { amounts were correctly attributed to } \\
\text { the taxpayers initially) }\end{array}$ & $\begin{array}{l}756 \text { files } \\
319.6 \\
\text { mill. RON }\end{array}$ & $\begin{array}{l}734 \text { files } \\
395.7 \\
\text { mill. RON }\end{array}$ & $\begin{array}{l}n / a \\
685.2 \\
\text { mill. RON }\end{array}$ & $\begin{array}{l}943 \text { files } \\
2.1 \\
\text { bill. RON }\end{array}$ & $\begin{array}{l}762 \text { files } \\
407.7 \\
\text { mill. RON }\end{array}$ \\
\hline $\begin{array}{l}\text { Number of files that were admitted } \\
\text { and the total amounts of fiscal } \\
\text { obligations annulled by the judicial } \\
\text { courts, in favor of the taxpayers } \\
\text { In \%, amounts of fiscal obligations } \\
\text { annulled in favor of the taxpayer from } \\
\text { the total amounts disputed in court }\end{array}$ & $\begin{array}{l}2516 \\
\text { judicial } \\
\text { claims } \\
91.9 \text { mill. } \\
\text { RON } \\
22.3 \%\end{array}$ & $\begin{array}{l}483 \\
\text { judicial } \\
\text { claims } \\
112.3 \\
\text { mill. RON } \\
22.1 \%\end{array}$ & $\begin{array}{l}\text { n/a } \\
201.8 \\
\text { mill. RON } \\
22.8 \%\end{array}$ & $\begin{array}{l}583 \\
\text { judicial } \\
\text { claims } \\
454.7 \\
\text { mill. RON } \\
17.5 \%\end{array}$ & $\begin{array}{l}420 \\
\text { judicial } \\
\text { claims } \\
118.2 \\
\text { mill. RON } \\
21.96 \%\end{array}$ \\
\hline
\end{tabular}

Source: NAFA annual performance reports

Although the number of actions/files decreased between 2013 and 2017, a more detailed analysis of the decisions reached following the judicial review provides a rather unexpected analogy with the decisions reached following 
the preliminary administrative procedure. As such, Table 4 showed that the value of the fiscal obligations that were contested and not settled by the end of the year seems to be disproportionately larger when compared to their number. In the case of the judicial review, according to Table 5, it seems that although a vast majority of the actions/files made were admitted, the total amounts of fiscal obligations annulled in favor of the taxpayer by the judicial courts are well below a quarter of the amounts contested in court. For example, in 2013, from the 3272 files in which the judicial courts verified the legality and validity of the fiscal obligations, 2516 were admitted; however, the total amounts of fiscal obligations annulled by these decisions in favor of the taxpayer account for only $22.3 \%$ of the amounts contested in court. The same phenomena can be identified in the entire analyzed period; for example, in 2017 there were 1182 judicial claims, 420 were admitted in favor of taxpayers, but they accounted for only $21.96 \%$ of the disputed amounts.

In essence, according to Table 5, it seems that although numerically most of the decision reached following the judicial procedure are in favor of taxpayers, when taking into account the amounts disputed, the judicial rulings tend to favor NAFA and maintain the initial fiscal obligations.

\subsection{The issue of effectiveness: multiple perspectives}

The effectiveness of the preliminary administrative procedure in fiscal matters can be analyzed from multiple perspectives, pertaining to the actors that have a direct or indirect legitimate interest in this procedure. As such, three major categories of actors can be identified: (a) the courts, (b) taxpayers that make administrative appeals and (c) fiscal bodies that issued the fiscal administrative acts or which must offer an answer to the appeal. The fact that this procedure is mandatory (before the judicial one) should be stated from the onset; as such, since it is acting as a preliminary condition rather than an alternative mean of dispute resolution, it becomes harder to present arguments in favor of this procedure.

From the perspective of the courts, the effectiveness of the internal administrative appeal would mean that as a result of the administrative procedure, fewer cases that have as objects fiscal matters would reach the judicial phase. In other words, the more appeals are solved favorably for the claimant by the administrative body that has the competencies to offer a solution, the less reasons claimants would have to address the court (as the issue was decided in a favorable manner for them), thus there will be fewer cases in which the assistance of the court is required. It is also implied that the response given by the administrative body to the appeal is not only favorable to the claimant, but also in accordance with the fiscal legislation and factual status, thus preventing any further action from all the parts involved.

Unfortunately, given the nature of the data presented in Tables 2 to 4 and Table 5 this hypothesis (that more appeals decided in favor of the claimant 
at the administrative level decrease the number of court cases with the same object) cannot be tested. First of all, the nature of the indicators differs, thus direct comparisons between the analyzed years/periods are not advised. Secondly, and most important, a temporal causal link/mechanism cannot be established between the two, due to the different lengths of the preliminary administrative and of the judicial review. Although the administrative procedure takes place before the judicial one and has a fixed number of days in which the response must/should be given, this deadline is seldom respected by fiscal administrative bodies (as shown in Table 4), while the length of the judicial procedure varies too much to establish some sort of temporal causality or linkage (i.e. court ruling from 2017 might in fact results from action started in the same year, or in 2016 or even 2014). As such, it is rather impossible to assess the effects of the solutions of administrative appeals on the number of cases that enter the judicial review phase or on the decisions taken at this level. Even if it is obvious that all the cases that were offered a judicial solution had previously undergone trough the internal administrative procedure at some point, we cannot establish exactly when the cases that received a judicial solution exited the administrative procedure.

The same perception of effectiveness (that fewer cases that have as objects fiscal matters would reach the judicial phase following the internal administrative appeal) could be shared, to some extension, by taxpayers. First of all, it should be mentioned that their initial aim would be to avoid altogether having to deal with the administrative appeal or judicial review (if taxpayers would not have any contentions against fiscal administrative acts because these would be either done properly or better explained/justified). If some contentions do appear, it is more than safe to assume that the administrative appeal would be preferable to the judicial review (as the latter requires more financial resources and is more time consuming). Furthermore, the administrative appeal must be done in a written form; as such, taxpayers can either draft it themselves (but given the fact that they might not be accustomed with the procedure and legal requirements this would decrease the chances of a favorable answer) or hire a lawyer to draft it and represent them. If the second alternative is taken, this entails more financial costs for the taxpayer. Given that the answer might still be unfavorable to them and they will have to pursue their interest in the court, the entire procedure will be regarded as inefficient as it entails extra costs. There is another facet which should be discussed: what happens if the object of the appeal (the sum of money that the taxpayer considers that he should not pay) is lower than the costs (fees) of the legal counsel or lawyer which has to help the taxpayer draft the appeal? In this situation, we assume that the taxpayer will either formulate the action himself, thus decreasing his chances for a favorable response, or hire a lawyer (in which case, even if the answer is favorable, the lawyers' fee might not be). As such, the internal administrative appeal would be considered efficient if: (1) the procedure would be shorter and less complex (costly) than the judicial one and (2) if the answer would be favorable to them. 
The discussion regarding effectiveness becomes even more complicated when we take into consideration the perspectives of the administrative bodies that issued the fiscal administrative act or which have to deal with the appeal. From the perspective of the body that issued the fiscal administrative act, the appeal would be effective only if it would somehow reduce the probability for further judicial actions, without diminishing the resources of the administration or its image. However, there is a rather important issue that has to be addressed here: the motives of the issuing body. Most judicial/ administrative actions originate in the taxpayer's perception that the tax/fee he is required to pay is either illegitimate/illegal or too big. As such, the aim of the fiscal body is to obtain as much money as possible (in the conditions of the law), while the aim of the taxpayer is to pay as little as possible. If the response to the appeal is favorable to the claimant (reducing or eliminating his contribution), the fiscal body that issued the act will regard the appeal as ineffective (or negative) as it reduces the resources/revenues it was supposed to collect. On the other hand, if the response is negative for the claimant (his fiscal duties are not reduced) then the issuing body will/can regard the appeal, at prima facie, as effective (as it did not diminish his resources); however, if the tax payer goes to court then the administrative appeal loses some of its perceived effectiveness as the body that issued the act will also have to be present in court (and consume resources to prepare the trial); even if the case is won or lost by the fiscal body, the judicial process in itself entails additional costs, thus raising the likelihood of a negative perception.

Last but not least, there is an issue that applies both to the body that issued the fiscal administrative act and to the body that has to respond to the appeal: the internal administrative procedure assumes/entails costs: it is another activity for that requires time and resources, without eliminating the possibility of an appearance in front of the court, regarding the same issue (administrative act). As such, it would be reasonable to assume that administrative bodies whose acts are contested have an inherent tendency to look upon the internal administrative procedure in a rather negative way, or to consider it both inefficient and ineffective.

\section{Conclusion}

The fact that the preliminary fiscal administrative procedure is mandatory (before the judicial review) and not an actual alternative mean of dispute resolution seems to significantly impede its efficiency and effectiveness; as such, acting as a preliminary condition rather than an alternative, few arguments can be presented in favor of this procedure as it does not seem to bring a positive contribution to the status quo.

Unfortunately, fiscal administrative appeals seem to be settled in the detriment of the taxpayer, as around $50 \%$ of the value of the fiscal obligations were maintained after the administrative appeals were settled. Furthermore, 
between a third and a half of the values of fiscal obligations which were contested and settled received other solutions besides rejection or being admitted, as the administrative appeals was rejected for procedural reasons: dismissed as late, was formulated by a person who did not justify his quality, failure to provide specific reasons, res judicata, lack of jurisdiction of the fiscal authorities, renunciation, lack of object, suspension of the administrative appeal. As such, less than $5 \%$ of the value of the fiscal obligations that were settled between 2013 and 2017 were annulled (decided in favor of the tax payer), while in the same period over $20 \%$ of the amounts contested/disputed via judicial review were annulled in favor of the taxpayer. Furthermore, this procedure also seems to be time consuming for taxpayers, as although internal administrative appeals should be settled in 45 days, the solution/decision is provided, on average, only after 70 days.

According to the game theory analysis conducted in section 4.2, the internal administrative appeal can be efficient only from the perspectives of the courts (and only if it reduces their workload) and that of taxpayers (only if the answer to the appeal is favorable to them and administrative bodies do not pursue further court actions); the situations in which this type of appeal would be seen as favorable by fiscal institutions are rather limited, as the response to the appeal must not be favorable for the appellant and the appellant must not further engage in a judicial procedure following the negative solution; even so, some costs for the administrative bodies are incurred as part of the procedure.

One potential shortcoming of this research consist in the fact that the internal administrative procedure and judicial review were not further compared with alternatives dispute resolution procedures (conciliation, mediation, settlements, arbitration and so on) in the case of Romania or more generally at the European level; however, although such an approach would have provided a more nuanced and complete image of the issue at hand, this would have been beyond the initial scope of the current research (but it can represent a potentially interesting line of future reseach). 


\section{References}

Bartuševičienė, I. and Šakalytė, E. (2013). Organizational Assessment: Effectiveness vs. Efficiency. Social Transformations in Contemporary Society, 1, pp. 45-53.

Bentley, D. (2015). Revisiting Rights Theory and Principles to Prepare for Growing Globalisation and Uncertainty. International Conference on Taxpayer Rights, Washington DC, November 18-19, 2015. At <https:// taxpayerrightsconference.com/wp-content/uploads/2015/11/Revisiting_ Rights_TheoryPDF.pdf>, accessed 4 October 2019.

Codagnone, C. (2008). Efficiency and Effectiveness. European Journal of ePractice, 4, pp. 2-3.

Cornall, R. (2008). The Effectiveness and Efficiency of Administrative Law: The Governmental Perspective. AIAL Forum, 58, pp. 56-67.

Council of Europe, Recommendation CM/Rec(2007)7 of the Committee of Ministers to Member States on Good Administration, adopted by the Committee of Ministers on 20 June 2007.

Council of Europe, Recommendation no. R(80) Concerning the Exercise of Discretionary Powers by Administrative Authorities, adopted by the Committee of Ministers on 11 March 1980.

Council of Europe, Recommendation Rec(2001) 9 of the Committee of Ministers to Member States on Alternatives to Litigation between Administrative Authorities and Private Parties, adopted by the Committee of Ministers on 5 September 2001.

Cucić, V. (2011a). Administrative Appeal in Serbian Law. Transylvanian Review of Administrative Sciences, 32E, pp. 50-73.

Cucić, V. (2011b). Appeals in Special Administrative Domains. Transylvanian Review of Administrative Sciences, 34E, pp. 63-79.

Darcy, G. and Paillet, M. (2000). Contentieux administratif. Paris: Dalloz, Armand Colin.

Dragoș, D.C. (2011). Alternative Dispute Resolution Mechanisms in the Field of Public Procurement: Between Effectiveness and Constitutionality. Transylvanian Review of Administrative Science, 34E, pp. 98-113.

Dragoș, D.C. and Neamțu, B. (2013). Effectiveness of Administrative Appeals Empirical Evidence from Romanian Local Administration. Lex Localis - Journal of Local Self-Government, 11(1), pp. 71-85.

Dragoș, D.C., Swora, M. and Skoczylas, A. (2012). Administrative Appeals in Romania and Poland - A Topical Comparative Perspective. Transylvanian Review of Administrative Science, 37E, pp. 38-54.

European Union. (2015). Economic Efficiency and Legal Effectiveness of Review and Remedies Procedures for Public Contracts. Luxembourg: Publications Office of the European Union.

Evans, J.M. (1993). Administrative Appeal or Judicial Review: A Canadian Perspective. Acta Juridica, 1993, pp. 47-75.

Internal Revenue Service. (2014). Taxpayer Bill of Rights. At <https://www.irs. gov/pub/irs-pdf/p5170.pdf>, accessed 5 October 2019.

International Monetary Fund. (2013). How Can an Excessive Volume of Tax Disputes Be Dealt With? At <https://www.imf.org/external/np/leg/ tlaw/2013/eng/tdisputes.pdf>, accessed 5 October 2019. 
lo Storto, C. and Goncharuk, A.G. (2017). Efficiency vs Effectiveness: a Benchmarking Study on European Healthcare Systems. Economics and Sociology, 10(3), pp. 102-115.

Klonowska, A. (2017). Standards Applied in Protection of Taxpayers' Rights. Scientific Journal WSFiP, 3/2017, pp. 93-110.

Kovač, P. (2013). Effective Adjudication through Administrative Appeals in Slovenia. Utrecht Law Review, 9(3), pp. 39-50.

Macarie, F.C. and Moldovan, O. (2018). Evaluating Romanian Internal Public Auditing Using the IA-CM: Current State and Potential Developments. In C.M. Hințea, B.A. Moldovan, B.V. Radu and R.M. Suciu, eds., Transylvanian International Conference in Public Administration. Cluj-Napoca: Accent, pp. 280-302.

Mandl, U., Dierx, A. and Ilzkovitz, F. (2008). The Effectiveness and Efficiency of Public Spending. Brussels: European Commission / Directorate-General for Economic and Financial Affairs.

McCormick, J.S. (1981). Effectiveness and Efficiency. The Journal of the Royal College of General Practitioners, 31(226), pp. 299-302.

Milovanović, D., Davinić, M. and Cucić, V. (2012). Efficiency of the Administrative Appeal (The Case of Serbia). Transylvanian Review of Administrative Sciences, 37E, pp. 95-111.

Miranda, C.O. (2006). Administrative Appeals and Judicial Review in Immigration Law: Where Matters Stand at the Beginning of the 21st Century. Catholic University Law Review, 55(4), pp. 917-922.

Moldovan, O. (2016). Local Revenue Mobilization in Romania. European Financial and Accounting Journal, 11(3), pp. 107-124.

Moldovan, O. (2017). Parteneriatul public-privat în România: O oportunitate ratată (En.: Public-Private Partnership in Romania: A Missed Opportunity). Revista Transilvană de Ştiinţe Administrative, 19(40), pp. 60-77.

National Agency for Fiscal Administration (NAFA). (2014a). Statistical Fiscal Bulletin no. 4/2013. At <http://static.anaf.ro/static/10/Anaf/Informatii_R/ Buletin_statistic_fiscal_4_2013.pdf>, accessed 10 March 2019.

National Agency for Fiscal Administration (NAFA). (2014b). 2013 Performance Report. At <http://static.anaf.ro/static/10/Anaf/Informatii_R/RAPORT_ PERFORMANTA_2013.pdf>, accessed 15 March 2019.

National Agency for Fiscal Administration (NAFA). (2015a). Statistical Fiscal Bulletin no. 4/2014. At <http://static.anaf.ro/static/10/Anaf/Informatii_R/ Buletin_statistic_fiscal_4_2014.pdf>, accessed 10 March 2019.

National Agency for Fiscal Administration (NAFA). (2015b). 2014 Performance Report. At < http://static.anaf.ro/static/10/Anaf/Informatii_R/Raport_2014_ V10_RO_24042015.pdf>, accessed 15 March 2019.

National Agency for Fiscal Administration (NAFA). (2016a). Statistical Fiscal Bulletin no. 4/2015. At <https://static.anaf.ro/static/10/Anaf/Informatii_R/ Buletin_statistic_fiscal4_2015.pdf>, accessed 10 March 2019.

National Agency for Fiscal Administration (NAFA). (2016b). 2015 Performance Report. At <https://static.anaf.ro/static/10/Anaf/Informatii_R/Raport_ performanta_20042016.pdf>, accessed 15 March 2019.

National Agency for Fiscal Administration (NAFA). (2017a). Statistical Fiscal Bulletin no. 4/2016. At <https://static.anaf.ro/static/10/Anaf/Informatii_R/ Buletin_statistic_fiscal_nr_4_2016_05042017.pdf>, accessed 10 March 2019. 
National Agency for Fiscal Administration (NAFA). (2017b). 2016 Performance Report. At <https://static.anaf.ro/static/10/Anaf/Informatii_R/Raport_ performanta2016_07042017.pdf>, accessed 15 March 2019.

National Agency for Fiscal Administration (NAFA). (2018a). Statistical Fiscal Bulletin no. 4/2017. At <https://static.anaf.ro/static/10/Anaf/Informatii_R/ Buletin_fiscal_4_2017.pdf>, accessed 10 March 2019.

National Agency for Fiscal Administration (NAFA). (2018b). 2017 Performance Report. At <https://static.anaf.ro/static/10/Anaf/Informatii_R/Raport_ performanta_2017_26032018.pdf> accessed 20 March 2019.

OECD. (2010). Policy Framework for Effective and Efficient Financial Regulation. General Guidance and High-Level Checklist. OECD.

OECD. (1990). Taxpayers' Rights and Obligations - Practice Note. At <https:// www.oecd.org/tax/administration/Taxpayers'_Rights_and_ObligationsPractice_Note.pdf>, accessed 4 October 2019.

Parsly, D. (2007). The Internal Revenue Service and Alternative Dispute Resolution: Moving From Infancy to Legitimacy. Cardozo Journal of Conflict Resolution, 8.2, pp. 677-715.

Ransome, K. (2008). The Effectiveness and Efficiency of Administrative Law: The Tribunal Perspective. AlAL Forum, 58, pp. 68-73.

Romanian Government, Ordinance no. 92/2004 regarding the Fiscal Procedure Code, published in the Official Journal of Romania, Part I, no. 941 from December 29, 2003 (replaced by Law no. 207/2015).

Romanian Parliament, Law no. 207/2015 regarding the Fiscal Procedure Code, published in the Official Journal of Romania, Part I, no. 547 from July 23, 2015.

Romanian Parliament, Law no. 554/2004 regarding the Administrative Court Procedure, published in the Official Journal of Romania, Part I, no. 1154 from 7 December 2004.

Sourdin, T. (2015). Evaluating Alternative Dispute Resolution in Tax Disputes. At <https://www.ato.gov.au/About-ATO/Research-and-statistics/In-detail/ General-research/Evaluating-alternative-dispute-resolution-in-taxationdisputes/>, accessed 3 October 2019.

Tăbârcă, M. (2009). Aspecte privitoare la procedura prealabilă reglementată de legea nг. 554/2004 a contenciosului administrativ (En.: Internal Administrative Appeals - Law no. 554/2004). Revista Transilvană de Ştiinţe Administrative, 11(23), pp. 89-96.

Themis Project. (1997). Judicial Control of Administrative Acts. Strasbourg: Council of Europe Publishing.

Tran-Nam, B. and Walpole, M. (2012). Independent Tax Dispute Resolution and Social Justice in Australia. UNSW Law Journal, 35(2), pp. 470-500.

Trinder, L. and Kellett, J. (2007). Fairness, Efficiency and Effectiveness in Courtbased Dispute Resolution Schemes in England. International Journal of Law, Policy and the Family, 21(3), pp. 323-340.

Ursuţa, M. (2012). Importanţa procedurii prealabile în litigiile de contencios administrativ derulate conform noului cod de procedură civilă (in En.: The Importance of the Preliminary Procedure in the Contentious-Administrative Litigations under the New Civil Procedure Code). Revista Transilvană de Ştiinţe Administrative, 14(31), pp. 152-161. 
Veny, L.M. and De Munck, E. (2011). Effectiveness of Administrative Appeals within the Framework of Administrative Justice in Belgium. Transylvanian Review of Administrative Sciences, 32E, pp. 277-293.

Voermans, W., ten Naper, H.-M. and Passchier, R. (2015). Combining Efficiency and Transparency in Legislative Processes. The Theory and Practice of Legislation, 3(3), pp. 279-294.

Willemsen, P., Gøtze, M. and Dragoş, D.C. (2010). Research Proposal: Effective Adjudication in Administrative Proceedings. Group X 'Law and Public Administration', EGPA 2010 Toulouse. At <http://vkc.library.uu.nl/vkc/ montaigne/research/Documents/Effective\%20adjudication\%20in\%20 administrative\%20proceedings.pdf>, accessed 22 February 2019.

World Bank. (2019). The Administrative Review Process for Tax Disputes: Tax Objections and Appeals in Latin America and the Caribbean. At <http:// documents.worldbank.org/curated/en/197591554404274707/pdf/TheAdministrative-Review-Process-for-Tax-Disputes-Tax-Objections-and-Appealsin-Latin-America-and-the-Caribbean-A-Toolkit.pdf>, accessed 2 August 2019. 